\title{
Voortijdige schoolverlaters
}

Citation for published version (APA):

Meng, C. M., \& Verhagen, A. M. C. (2013). Voortijdige schoolverlaters. ROA. ROA Fact Sheets No. 003 https://doi.org/10.26481/umarof.2013003

Document status and date:

Published: 01/01/2013

DOI:

10.26481/umarof.2013003

Document Version:

Publisher's PDF, also known as Version of record

\section{Please check the document version of this publication:}

- A submitted manuscript is the version of the article upon submission and before peer-review. There can be important differences between the submitted version and the official published version of record.

People interested in the research are advised to contact the author for the final version of the publication, or visit the DOI to the publisher's website.

- The final author version and the galley proof are versions of the publication after peer review.

- The final published version features the final layout of the paper including the volume, issue and page numbers.

Link to publication

\footnotetext{
General rights rights.

- You may freely distribute the URL identifying the publication in the public portal. please follow below link for the End User Agreement:

www.umlib.nl/taverne-license

Take down policy

If you believe that this document breaches copyright please contact us at:

repository@maastrichtuniversity.nl

providing details and we will investigate your claim.
}

Copyright and moral rights for the publications made accessible in the public portal are retained by the authors and/or other copyright owners and it is a condition of accessing publications that users recognise and abide by the legal requirements associated with these

- Users may download and print one copy of any publication from the public portal for the purpose of private study or research.

- You may not further distribute the material or use it for any profit-making activity or commercial gain

If the publication is distributed under the terms of Article $25 \mathrm{fa}$ of the Dutch Copyright Act, indicated by the "Taverne" license above, 
Tuastricht University in Learning!

Research Centre for Education and the Labour Market | ROA

\section{Voortijdige schoolverlaters}

\section{ROA Fact Sheet}

ROA-F-2013/3

Researchcentrum voor Onderwijs en Arbeidsmarkt | ROA Research Centre For Education and the Labour Market / ROA 


\section{Inleiding}

Het aantal nieuwe voortijdige schoolverlaters (vsv'ers) mag in het schooljaar 20I4/20I5 maximaal 25.000 bedragen. Het is daarom nu nog belangrijker om inzicht te krijgen in wat deze groep jongeren kenmerkt. Waarom stoppen ze met hun opleiding? Wat waren vroege signalen voor hun uitval? Wat is hun belangrijkste bezigheid anderhalf jaar na hun uitval? Zijn ze van plan weer terug te keren in het onderwijs? En hebben ze achteraf bezien spijt van hun beslissing om voortijdig hun opleiding te verlaten? Dit factsheet gaat in op de antwoorden op deze vragen.

De gepresenteerde resultaten zijn gebaseerd op de vragenlijsten die in het najaar van 2012 zijn afgenomen onder 2.033 ongediplomeerde vsv'ers. Dit zijn leerlingen die in het schooljaar 2010/20II zonder diploma hun opleiding in het voortgezet onderwijs (VMBO, HAVO of VWO) of in het MBO hebben verlaten zonder in het bezit te zijn van een startkwalificatie. Deze enquête onder ongediplomeerde vsv'ers maakt deel uit van de jaarlijkse schoolverlatersenquêtes van het Researchcentrum voor Onderwijs en Arbeidsmarkt (ROA). De schoolverlatersonderzoeken worden al sinds het begin van de jaren '9o door het ROA uitgevoerd. Voor een aantal onderdelen komen de vragen op vragenlijsten voor de ongediplomeerden en gediplomeerden overeen zodat vergelijkingen tussen beide groepen op een aantal belangrijke indicatoren mogelijk zijn. Gediplomeerden zijn in dit verband schoolverlaters die hun opleiding met een diploma verlaten, ongeacht of dit wel of niet een startkwalificatie is.

In dit factsheet wordt naast de resultaten van de totale groep ongediplomeerde vsv'ers nader ingezoomd op de groep "inactieve vsv'ers" (ook wel "NEETs" genoemd). Dit is de groep ongediplomeerde vsv'ers die ongeveer anderhalf jaar na hun voortijdige uitval niet zijn teruggekeerd in een opleiding of training, niet werken en ook niet op zoek zijn naar werk. $27 \%$ van de respondenten behoort tot deze groep en bevindt zich dan ook in een kwetsbare situatie.

\section{Achtergrondkenmerken respondenten}

Ten eerste worden hier enkele achtergrondkenmerken van de respondenten beschreven. Zie voor een uitgebreid overzicht van de achtergrondkenmerken per opleidingsniveau tabel $\mathrm{B}_{\mathrm{I}}$ in de bijlagen.

De in dit factsheet omschreven groep ongediplomeerde vsv'ers is niet gelijk aan de totale groep voortijdige schoolverlaters zoals die landelijk wordt gedefinieerd. Omdat de focus in dit onderzoek ligt op de redenen voor het stoppen met een opleiding, zijn de personen die wel een diploma hebben behaald maar geen startkwalificatie hebben (diploma van VMBO of $\mathrm{MBO}$ niveau I), niet in de steekproef opgenomen. Aangezien deze personen feite- lijk niet met hun opleiding zijn gestopt, kan er ook niet naar de redenen voor het stoppen met de opleiding worden gevraagd. De hier omschreven achtergrondkenmerken kunnen daarom afwijken van de achtergrondkenmerken van de totale populatie vsv'ers in Nederland.

\section{Opleidingsniveau}

Driekwart van de respondenten was in het schooljaar 2010/20II een opleiding op MBO-niveau aan het volgen (35\% MBO niveau I/2, 40\% MBO niveau 3/4), ongeveer twee op de tien volgde een opleiding op VMBO-niveau en de rest volgde een opleiding op HAVO of VWO niveau (AVO). Ook onder de inactieven volgde driekwart van de respondenten een opleiding op $\mathrm{MBO}$-niveau. Het percentage VMBO'ers en AVO'ers is onder de inactieven gelijk als onder de totale groep vsv-respondenten.

\section{Leeftijd en geslacht}

De respondenten zijn gemiddeld is jaar oud en de helft van hen is vrouw. Onder de respondenten uit het AVO zijn er verhoudingsgewijs iets meer meisjes dan jongens en onder de respondenten uit het $\mathrm{MBO}$ niveau I/2 zijn er relatief meer jongens dan meisjes. De gemiddelde leeftijd van de respondenten uit het VMBO is 17 , wat betekent dat de gemiddelde VMBO-respondent voortijdig is gestopt ondanks dat de kwalificatieplicht voor hem/haar nog van kracht was.

Vergeleken met de totale groep vsv-respondenten zijn er relatief iets meer meisjes onder de inactieven (54\%), maar de gemiddelde leeftijd is hetzelfde.

\section{Etniciteit}

De meerderheid van de respondenten is autochtoon (75\%), terwijl dit onder de gediplomeerde respondenten $84 \%$ is. Het percentage autochtonen is met name hoog onder de vsv-respondenten uit het AVO. Onder de respondenten uit het $\mathrm{VMBO}$ en $\mathrm{MBO}$ niveau $\mathrm{I} / 2$ zijn er relatief meer nietwesterse allochtonen.

Onder de groep inactieven zijn er vergeleken met de totale groep vsv-respondenten relatief iets meer allochtonen.

\section{Thuissituatie}

Iets meer dan de helft van de respondenten (53\%) komt uit een tweeouder gezin. Dit percentage is aanzienlijk lager dan onder de gediplomeerde respondenten (8I\%). De respondenten uit het $\mathrm{MBO}$ wonen vergeleken met de overige respondenten relatief vaak zelfstandig. Respondenten uit het AVO en VMBO wonen relatief vaak bij hun ouders. Respondenten die onder de categorie inactieven vallen, komen vergeleken met de totale groep vsv-respondenten veel minder vaak uit een tweeouder gezin (43\%).

Op alle opleidingsniveau geven veruit de meeste respondenten aan (bijna) altijd Nederlands of Nederlands en een andere taal te spreken met hun ouders. De ouders van respondenten uit het AVO zijn relatief vaak hoger opgeleid (HBO/WO). De ouders van respondenten uit het $\mathrm{MBO}$ niveau $\mathrm{I} / 2$ hebben relatief vakk een opleiding in het lager beroepsonderwijs gevolgd. Hoewel $95 \%$ van de respon- 
denten geen kinderen heeft, is het percentage met kinderen relatief het hoogst onder de respondenten uit het $\mathrm{MBO}$ niveau $\mathrm{I} / 2(7 \%)$ en het laagst onder respondenten uit het AVO (I\%).

De thuissituatie van de inactieven is over het algemeen vergelijkbaar met dat van de totale groep vsv-respondenten, behalve dat de inactieven relatief iets vaker angeven kinderen te hebben (9\%).

\section{Belangrijkste redenen om te stoppen}

Aan de vsv'ers is gevraagd wat voor hen de belangrijkste reden voor hun voortijdige uitval is geweest. In figuur I zijn deze belangrijkste redenen weergegeven per opleidingsniveau.

Figuur 1

Belangrijkste reden voor voortijdige uitval, per opleidingsniveau (\%)

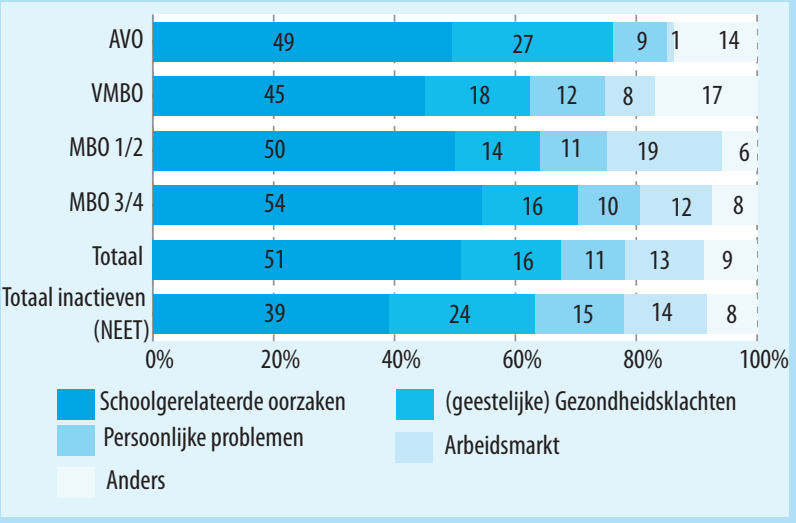

\section{Schoolgerelateerde oorzaken}

Net als in voorgaande jaren is 'schoolgerelateerde oorzaken' de vaakst genoemde belangrijkste reden voor de voortijdige uitval. Gaf echter in de meting van 2010 nog $41 \%$ van de respondenten aan te zijn gestopt vanwege schoolgerelateerde oorzaken (45\% in de meting van 20II), in de huidige meting is dit percentage gestegen naar $51 \%$. Deze stijging van ongeveer $5 \%$ punt is terug te zien op alle opleidingsniveaus.

Kijkend naar de onderliggende schoolgerelateerde subredenen (zie bijlage tabel $\mathrm{B}_{2}$ ), zien we dat 'de opleiding was inhoudelijk (toch) niet wat ik wilde', 'de opleiding was te moeilijk en/of gezakt voor het eindexamen' en 'de opleiding was slecht georganiseerd' het vaakst worden genoemd als de belangrijkste reden voor voortijdige uitval. Dit is vergelijkbaar met de meting in 2oIr.

De reden 'de opleiding was inhoudelijk (toch) niet wat ik wilde' wordt met name vaak genoemd door respondenten van $\mathrm{MBO}$ niveau $3 / 4$ ( $16 \%$ ). Het percentage VMBO'ers dat deze reden als de belangrijkste reden noemt is ten opzichte van de vorige meting gestegen van $2 \%$ naar $8 \%$.

De reden 'de opleiding was te moeilijk en/of gezakt' is met name hoog onder respondenten van het AVO (27\%) en $\mathrm{MBO}$ niveau $\mathrm{I} / 2$ (IO\%). Vorig jaar was het percentage respondenten van het $\mathrm{AVO}$ dat deze reden als belangrijkste reden noemde nog aanzienlijk lager ( $17 \%)$. Ook in het $\mathrm{MBO}$ is er ten opzichte van de vorige meting een lichte stijging van dit percentage te zien. Alleen onder de respondenten van het $\mathrm{VMBO}$ is het percentage dat deze reden als belangrijkste reden noemt niet gestegen ten opzichte van vorig jaar.

De reden 'de opleiding was slecht georganiseerd' wordt net als vorig jaar met name vaak als belangrijkste reden genoemd door respondenten van $\mathrm{MBO}$ niveau $3 / 4$.

\section{(Geestelijke) Gezondheidsklachten}

Kijkend naar het totaal, zien we dat de (geestelijke) gezondheidsklachten op de tweede plaats staan wat betreft de vaakst genoemde belangrijkste redenen voor voortijdige uitval. Met name in het AVO (27\%) en onder de inactieven $(24 \%)$ is het percentage respondenten dat aangeeft te zijn gestopt vanwege deze reden relatief hoog.

Subredenen die onder deze categorie vallen zijn 'fysieke gezondheidsproblemen (ziekte/handicap)', 'psychische problemen' en 'verslavingsproblemen'. Ook deze subredenen worden relatief vaak genoemd onder respondenten van het $\mathrm{AVO}$ en onder de inactieven.

Ten opzichte van vorig jaar zien we dat het percentage respondenten van het $\mathrm{VMBO}$ dat aangeeft dat (geestelijke) gezondheidsklachten de belangrijkste reden was om voortijdig te stoppen aanzienlijk is gedaald, van $27 \%$ naar $18 \%$. Dit komt door een daling van het percentage VMBO'ers dat aangeeft te zijn gestopt vanwege psychische problemen.

\section{Persoonlijke problemen}

Op alle opleidingsniveaus worden persoonlijke problemen door ongeveer een op de tien respondenten als belangrijkste reden genoemd. Het percentage ligt iets hoger onder de groep inactieven $(15 \%)$.

De vaakst genoemde subreden die onder deze categorie valt is 'relatieproblemen / gezinsproblemen (bijv. scheiding van ouders)'. Op alle opleidingsniveaus geeft ongeveer $5 \%$ van de respondenten aan dat dat de belangrijkste reden was om voortijdig te stoppen. Hetzelfde geldt voor de groep inactieven.

\section{Arbeidsmarkt}

Iets meer dan een op de tien respondenten geeft aan dat een arbeidsmarkt gerelateerde reden de belangrijkste reden was voor de voortijdige uitval. Net als voorgaande jaren wordt deze reden met name vaak genoemd door de respondenten van het $\mathrm{MBO}$. Dit is niet verrassend gezien het feit dat deze jongeren in hun studie in aanraking komen met de arbeidsmarkt door middel van een leerwerkplek of stage.

Kijkend naar de arbeidsmarkt gerelateerde subredenen, zien we dat 'ik wilde liever gaan werken' het vaakst als belangrijkste reden wordt genoemd ( $8 \%)$. Het percentage dat deze reden als de belangrijkste reden voor voortijdige uitval noemt, is relatief iets hoger onder respondenten van $\mathrm{MBO}$ niveau $\mathrm{I} / 2$ dan van $\mathrm{MBO}$ niveau $3 / 4$. 


\section{Vroege signalen bij uitval}

Aan de vsv'ers is een aantal vragen gesteld om te achterhalen of er, achteraf bezien, vroege signalen van hun voortijdige uitval zijn geweest.

\section{Praten over de beslissing}

Het meest herkenbare vroege signaal van voortijdige uitval is waarschijnlijk het moment dat de jongere met iemand praat over de beslissing om voortijdig met de opleiding te stoppen. Daarom is aan de vsv'ers gevraagd of ze met iemand hebben gesproken over hun beslissing om voortijdig te stoppen, en zo ja met wie. Tabel I laat zien dat, achteraf bezien, dit vroege signaal bij veruit de meeste respondenten $(80 \%)$ aanwezig is geweest. Onder de respondenten van het AVO is het percentage dat aangeeft met iemand over de beslissing te hebben gesproken nog hoger (89\%).

De meeste respondenten die met 'iemand' over hun beslissing om voortijdig te stoppen hadden gesproken, geven aan dat ze (onder andere) met hun ouders over de beslissing hadden gesproken (68\%). Dit percentage is relatief hoog onder de respondenten van het AVO (87\%), en aanzienlijk lager onder respondenten van $\mathrm{MBO}$ niveau $\mathrm{I} / 2$ (6I\%) en onder de inactieven (60\%).

Daarnaast is er een relatief grote groep respondenten (48\%) die aangeeft (onder andere) met iemand in school te hebben gesproken over de beslissing om met de opleiding te stoppen. Wederom is het percentage relatief hoog onder respondenten van het $\mathrm{AVO}(56 \%)$, maar hier zijn het - naast de inactieven $(38 \%)$ - de respondenten uit het VMBO met een relatief laag percentage $(38 \%)$. Dit komt met name omdat de VMBO'ers relatief minder vaak aangeven met hun leraren en/of mentor te hebben gesproken over hun beslissing om te stoppen. Tabel $\mathrm{B}_{\mathrm{I}}$ in de Bijlage liet zien dat de gemiddelde leeftijd van de respondenten van het VMBO I7 jaar is, wat betekent dat de gemiddelde vsv-respondent van dit niveau nog onder de kwalificatieplicht valt. Daardoor is het nog zorgwekkender dat slechts $38 \%$ van de respondenten uit het VMBO aangeeft met iemand in school te hebben gesproken over de beslissing om te stoppen.

Over het algemeen geven de respondenten die aangeven (onder andere) met iemand in school te hebben gesproken, aan dat ze (onder andere) met hun mentor hebben gesproken. Het is niet verrassend dat relatief weinig respondenten aangeven dat ze (onder andere) met het zorgadviesteam hebben gesproken, aangezien het contact met het zorgadviesteam doorgaans via de mentor loopt.

\section{Aangeboden hulp}

Dat er een herkenbaar vroeg signaal van voortijdige uitval is geweest, hoeft niet per definitie te betekenen dat er ook geprobeerd is om te helpen om de uitval te voorkomen, of dat geboden hulp als zodanig door de jongere is ervaren. Daarom is de vsv'ers gevraagd of de school (leraar, mentor, schoolleiding, zorgadviesteam) of andere instanties (bijv. de leerplichtambtenaar) heeft geprobeerd te helpen zodat ze ondanks hun situatie hun diploma konden halen of van opleiding konden wisselen.

Bijna de helft van de respondenten (47\%) geeft aan het idee te hebben dat niemand (de school noch andere instanties) heeft geprobeerd te helpen om de voortijdige uitval te voorkomen (zie tabel 2). Dit percentage is vergelijkbaar met vorig jaar $(45 \%)$. Onder de groep inactieven heeft zelfs de meerderheid $(56 \%)$ het idee dat niemand heeft geprobeerd te helpen om de voortijdige uitval te voorkomen.

Op alle opleidingsniveaus heeft ongeveer 45 tot $50 \%$ het idee dat niemand geprobeerd heeft te helpen om de voortijdige uitval te voorkomen. Toch had vorig jaar 'slechts' $28 \%$ van de VMBO'ers het idee dat niemand had geprobeerd te helpen; een stijging van $14 \%$ punten.

De respondenten die aangeven dat (geestelijke) gezondheidsklachten of persoonlijke problemen de belangrijkste reden voor hun voortijdige uitval was, geven relatief het vaakst aan dat er 'iemand' heeft geprobeerd te helpen om hun voortijdige uitval te voorkomen $(64 \%$, resp. $60 \%)$. Bij de overige belangrijkste redenen van voortijdige uitval is het percentage dat aangeeft dat 'iemand' heeft geprobeerd te helpen rond de $50 \%$.

Ongeveer tweederde van de respondenten die aangeven met niemand te hebben gesproken over hun beslissing om voortijdig te stoppen, hebben ook het idee dat niemand heeft geprobeerd te helpen. Dat lijkt aan te geven aan dat praten over de beslissing een belangrijke eerste stap kan zijn in het aangeboden krijgen van hulp. Toch geeft maar liefst $42 \%$ van de respondenten die aangeven met 'iemand' te hebben gesproken over de beslissing, aan dat ze desondanks niet het idee hebben dat iemand heeft geprobeerd te helpen. Als we kijken naar met wie deze respondenten dan hebben gesproken, zien we dat met name de vsv'ers die (onder andere) met hun broer(s) en/of zus(sen), hun vrienden en/ of hun ouders hebben gesproken, het idee hebben dat de school noch andere instanties hebben geprobeerd te helpen. Dit zou erop kunnen duiden dat het 'sociale net' rondom de jongeren die dreigen uit te vallen niet altijd effectief is in het inschakelen van de school of andere instanties om de voortijdige uitval te voorkomen.

Toch lijkt de school zelf ook niet altijd effectief te zijn in (het overbrengen van) pogingen om te helpen. Van de respondenten die aangeven dat ze (onder andere) met iemand in school hadden gesproken, geeft $35 \%$ aan niet het idee te hebben dat de school of andere instanties hebben geprobeerd te helpen om de voortijdige uitval te voorkomen.

\section{Spijbelgedrag}

Een ander mogelijk vroeg signaal van voortijdige uitval is spijbelgedrag. Voortijdige schooluitval wordt immers vaak voorafgegaan door langdurig spijbelen (of 'thuiszitten'). In tabel 3 is te zien dat de meerderheid van de respondenten aangeeft wel eens te hebben gespijbeld ( $55 \%)$. Dit is een lichte daling ten opzichte van vorig jaar $(60 \%)$. Met name in het $\mathrm{VMBO}$ en $\mathrm{MBO}$ niveau $\mathrm{I} / 2$ zijn er minder (zelfgerapporteerde) spijbelaars dan vorig jaar; in beide groepen 
Tabel 1

Met wie heb je gesproken over je keuze om met de opleiding te stoppen? (meerdere antwoorden mogelijk) (\%)

\begin{tabular}{|c|c|c|c|c|c|c|}
\hline & AV0 & VMBO & MBO 1/2 & $\mathrm{MBO} 3 / 4$ & Totaal & Totaal inactieven (NEET) \\
\hline Niemand & 11 & 24 & 24 & 16 & 20 & 24 \\
\hline lemand & 89 & 76 & 76 & 84 & 80 & 77 \\
\hline Ouders & 87 & 68 & 61 & 72 & 68 & 60 \\
\hline Broer(s) en/of zus(sen) & 15 & 7 & 7 & 15 & 11 & 11 \\
\hline Vrienden & 29 & 10 & 11 & 30 & 20 & 19 \\
\hline School & 56 & 38 & 46 & 54 & 48 & 38 \\
\hline Leraren & 24 & 15 & 19 & 20 & 19 & 17 \\
\hline Mentor & 43 & 31 & 32 & 42 & 37 & 32 \\
\hline Schoolleiding & 31 & 18 & 11 & 12 & 14 & 15 \\
\hline Zorgadviesteam & 14 & 16 & 8 & 13 & 12 & 7 \\
\hline
\end{tabular}

Tabel 2

Wie heeft geprobeerd te helpen om de voortijdige uitval te voorkomen? (\%)

\begin{tabular}{|c|c|c|c|}
\hline & $\begin{array}{r}\text { Niemand } \\
\text { (school noch andere instanties) }\end{array}$ & $\begin{array}{r}\text { lemand } \\
\text { (school of andere instanties) }\end{array}$ & Totaal \\
\hline Totaal & 47 & 53 & 100 \\
\hline Inactieven (NEET) & 56 & 44 & 100 \\
\hline \multicolumn{4}{|l|}{ Opleidingsniveau } \\
\hline AVO & 43 & 57 & 100 \\
\hline VMBO & 44 & 56 & 100 \\
\hline MBO $1 / 2$ & 45 & 55 & 100 \\
\hline $\mathrm{MBO} 3 / 4$ & 51 & 49 & 100 \\
\hline \multicolumn{4}{|l|}{ vsv reden } \\
\hline Schoolgerelateerde oorzaken & 46 & 54 & 100 \\
\hline (geestelijke) gezondheidsklachten & 36 & 64 & 100 \\
\hline persoonlijke problemen & 40 & 60 & 100 \\
\hline arbeidsmarkt & 47 & 53 & 100 \\
\hline anders & 49 & 51 & 100 \\
\hline \multicolumn{4}{|l|}{ met wie gesproken } \\
\hline Niemand & 64 & 36 & 100 \\
\hline lemand & 42 & 59 & 100 \\
\hline Ouders & 42 & 58 & 100 \\
\hline Broer(s) en/of zus(sen) & 45 & 55 & 100 \\
\hline Vrienden & 44 & 56 & 100 \\
\hline School & 35 & 65 & 100 \\
\hline
\end{tabular}

Tabel 3

Spijbelgedrag (\%)

\begin{tabular}{|c|c|c|c|c|c|c|}
\hline & AV0 & VMBO & MBO $1 / 2$ & $\mathrm{MBO} 3 / 4$ & Totaal & Totaal inactieven (NEET) \\
\hline Nooit gespijbeld & 47 & 61 & 49 & 34 & 45 & 42 \\
\hline Heel soms gespijbeld & 38 & 26 & 36 & 44 & 38 & 39 \\
\hline Ongeveer één of twee keer per week gespijbeld & 10 & 7 & 9 & 16 & 11 & 12 \\
\hline (bijna) dagelijks gespijbeld & 5 & 6 & 7 & 7 & 7 & 7 \\
\hline Totaal & 100 & 100 & 100 & 100 & 100 & 100 \\
\hline
\end{tabular}


is er een daling van ongeveer IO\%punt. Daarentegen is het aantal spijbelaars in het AVO ten opzichte van vorig jaar enigszins gestegen van $48 \%$ naar $53 \%$. De respondenten van $\mathrm{MBO}$ niveau 3/4 zijn nog altijd de meest frequente (zelfgerapporteerde) spijbelaars.

\section{Huidige bezigheid}

\section{Belangrijkste bezigheid}

Om een indicatie te krijgen van wat de respondenten als hun belangrijkste bezigheid zien op het enquêtemoment (ongeveer anderhalf jaar na de voortijdige uitval), is hen gevraagd wat ze nu doen (zie tabel 4 ). Het merendeel van de respondenten heeft ongeveer anderhalf jaar na de voortijdige uitval als belangrijkste bezigheid studeren (39\%) of werken $(37 \%)$. Dit hoeft echter niet per definitie te betekenen dat $37 \%$ van de respondenten tot de werkzame beroepsbevolking behoort. Het is mogelijk dat een deel van deze respondenten minder dan I2 uur per week werkt, vrijwilligerswerk doet of zwart werkt.

Hoewel het merendeel van de respondenten uit het AVO en VMBO na anderhalf jaar aangeeft te zijn teruggekeerd in het onderwijs, is dit bij de respondenten uit het $\mathrm{MBO}$ niet het geval. Van de respondenten uit $\mathrm{MBO}$ niveau $\mathrm{I} / 2$ heeft de meerderheid (54\%) werk als belangrijkste bezigheid. In $\mathrm{MBO}$ niveau 3/4 zijn er ongeveer net zo veel respondenten die aangeven dat werk hun belangrijkste bezigheid is, als dat er respondenten zijn die aangeven dat hun belangrijkste bezigheid een studie is.

Ten opzichte van het vorige meetjaar is de belangrijkste bezigheid van de respondenten uit het VMBO ongeveer gelijk gebleven. De respondenten van het AVO en $\mathrm{MBO}$ niveau $3 / 4$ zijn relatief vaker teruggekeerd in het onderwijs in plaats van te gaan werken. De respondenten van $\mathrm{MBO}$ niveau $\mathrm{I} / 2$ geven ten opzichte van vorig jaar relatief vaker aan te zijn gaan werken.

Met name de respondenten die destijds waren gestopt vanwege arbeidsmarkt gerelateerde oorzaken, hebben ongeveer anderhalf jaar later als belangrijkste bezigheid 'werk' (66\%). Respondenten die waren gestopt vanwege 'andere redenen', schoolgerelateerde oorzaken of geestelijke gezondheidsklachten keren relatief het vaakst terug in het onderwijs.

\section{Arbeidsmarktindicatoren}

Tabel 5 geeft een overzicht van enkele van de belangrijkste arbeidsmarktindicatoren voor zowel de vsv'ers als voor de respondenten die wel een startkwalificatie hebben behaald (diploma van HAVO, VWO of MBO niveau 2). Voor de meeste indicatoren lijkt het behalen van een startkwalificatie positief samen te hangen met succes op de arbeidsmarkt. De vsv-respondenten zijn gemiddeld relatief vaker werkloos, en als ze wel een baan hebben gevonden, hebben ze vaker een tijdelijke aanstelling, en hebben ze gemiddeld een lager bruto uurloon en - maandloon dan de respon- denten met een startkwalificatie. Dit maakt de vsv'ers een kwetsbare groep op de arbeidsmarkt.

Ten opzichte van het vorige meetjaar is de werkloosheid onder de vsv-respondenten licht gestegen (van 20\% naar $23 \%)$. Van de respondenten die wel werk hebben gevonden, is het gemiddelde bruto uurloon gedaald van $€ 7,26$ naar $€ 7,05$, en het gemiddelde bruto maandloon van €99I naar €95I. De overige arbeidsmarktindicatoren zijn voor de totale groep vsv-respondenten vergelijkbaar met het vorige meetjaar.

Van de vsv-respondenten zijn de VMBO'ers het meest kwetsbaar op de arbeidsmarkt. Deze respondenten scoren relatief het slechtst op alle weergegeven arbeidsmarktindicatoren. Maar liefst $40 \%$ van hen is werkloos, en van degenen die wel een baan hebben kunnen vinden heeft tweederde een tijdelijke aanstelling. Bovendien werken ze gemiddeld voor een relatief laag loon ( $€ 5,75 /$ uur, $€ 603 /$ maand). Het gemiddelde bruto maandloon van de vsv-respondenten van het $\mathrm{VMBO}$ is bovendien lager dan vorig jaar (€657).

Hoewel de werkloosheid onder respondenten van $\mathrm{MBO}$ niveau I/2 met $28 \%$ relatief hoog is, scoren degenen die wel werk hebben weten te vinden, relatief beter op de overige arbeidsmarktindicatoren vergeleken met respondenten van de meeste andere opleidingsniveaus. Ten opzichte van de vorige meting is het aandeel werkende vsv'ers van $\mathrm{MBO}$ niveau $\mathrm{I} / 2$ met een vast contract zelfs gestegen, van $40 \%$ naar $47 \%$. Het gemiddelde bruto uurloon en - maandloon is daarentegen gedaald van respectievelijk $€ 7,4 \mathrm{I}$ naar $€ 6,87$ en van $€ \mathrm{I} .072$ naar $€ 93 \mathrm{I}$.

De werkloosheid onder de vsv-respondenten van het AVO is vrij laag (9\%). Het is zelfs iets lager dan onder de respondenten met een startkwalificatie (II\%). Dit is een groot verschil ten opzichte van vorig jaar; toen was het werkloosheidspercentage onder de respondenten van het AVO drie keer zo hoog (25\%). Het lijkt erop dat de werkloosheid binnen deze groep zo sterk is gedaald omdat ze vaker dan voorheen werk hebben gevonden/geaccepteerd met relatief slechtere baankenmerken. Zo is ten opzichte van vorig jaar het aandeel tijdelijke aanstellingen onder de werkende respondenten van het AVO gestegen van $41 \%$ naar $50 \%$, en is het bruto uurloon en - maandloon gedaald van gemiddeld $€ 7,48$ naar $€ 6,08$ en van $€ 872$ naar $€ 63$ I.

Andere belangrijke arbeidsmarktindicatoren zijn de tevredenheid met de huidige functie (figuur 2), carrièremogelijkheden in de huidige functie (figuur 3), en het door de werkgever vereiste opleidingsniveau in de huidige functie (figuur 4).

Van de respondenten die anderhalf jaar na de voortijdige uitval een baan hebben, is het merendeel (58\%) tevreden of zeer tevreden met de functie. Dit percentage is echter wel lager dan onder de respondenten met een startkwalificatie $(67 \%)$. Vergeleken met hen zijn de vsv-respondenten relatief vaker (zeer) ontevreden met de huidige functie.

Wederom zien we een indicatie dat de respondenten van het AVO vergeleken met vorig jaar vaker een baan hebben aangenomen met relatief slechtere kenmerken; hoewel relatief veel respondenten van AVO-niveau zijn gaan werken, 
Tabel 4

Belangrijkste bezigheid op enquêtemoment (\%)

\begin{tabular}{|c|c|c|c|c|c|}
\hline & Werk & Studie & Combinatie werken/leren & Anders & Totaal \\
\hline Totaal & 37 & 39 & 6 & 18 & 100 \\
\hline \multicolumn{6}{|l|}{ Opleidingsniveau } \\
\hline AV0 & 8 & 77 & 2 & 13 & 100 \\
\hline VMBO & 13 & 73 & 4 & 11 & 100 \\
\hline MBO $1 / 2$ & 54 & 19 & 4 & 24 & 100 \\
\hline $\mathrm{MBO} 3 / 4$ & 38 & 36 & 9 & 17 & 100 \\
\hline \multicolumn{6}{|c|}{ Belangrijkste reden voortijdige uitval } \\
\hline Schoolgerelateerde oorzaken & 37 & 43 & 8 & 13 & 100 \\
\hline (Geestelijke) gezondheidsklachten & 20 & 42 & 2 & 35 & 100 \\
\hline Persoonlijke problemen & 35 & 31 & 7 & 27 & 100 \\
\hline Arbeidsmarkt & 66 & 15 & 4 & 15 & 100 \\
\hline Anders & 31 & 51 & 3 & 16 & 100 \\
\hline
\end{tabular}

Tabel 5

Werkloosheid en kenmerken huidige baan (anderhalf jaar na voortijdige uitval)*

\begin{tabular}{|c|c|c|c|c|c|c|}
\hline & AVO & VMBO & $\mathrm{MBO} 1 / 2$ & $\mathrm{MBO} 3 / 4$ & Totaal & AV0/MBO2 gediplomeerden \\
\hline werkloos (\%) & $9 \%$ & $40 \%$ & $28 \%$ & $17 \%$ & $23 \%$ & $11 \%$ \\
\hline Loondienst $(\%)^{*}$ & $78 \%$ & $54 \%$ & $74 \%$ & $70 \%$ & $71 \%$ & $67 \%$ \\
\hline Tijdelijke aanstelling (\%)* & $50 \%$ & $66 \%$ & $53 \%$ & $56 \%$ & $55 \%$ & $43 \%$ \\
\hline Arbeidsuren volgens contract (uren)* & 27 & 27 & 32 & 32 & 31 & 32 \\
\hline Bruto uurloon $(€)^{*}$ & 6,01 & 5,75 & 6,85 & 7,38 & 7,05 & 9,15 \\
\hline Bruto maandloon $(€)^{*}$ & 631 & 603 & 931 & 1011 & 951 & 1283 \\
\hline
\end{tabular}

*Selectie: werkzame beroepsbevolking (excl. studenten)

Tabel 6

Van plan om op een later tijdstip (nog) een opleiding te gaan volgen? (\%)*

\begin{tabular}{|l|r|r|r|r|r|r|} 
& MBO 3/4 & Totaal & totaal inactieven (NEET) \\
\hline ja, ik heb mij alweer ingeschreven bij een opleiding & 24 & 23 & 11 & 11 \\
\hline Ja, maar ik weet nog niet welke opleiding of wanneer & 71 & 57 & 5 & 68 & 63 \\
\hline Nee & 5 & 20 & 33 & 21 & 27 \\
\hline
\end{tabular}

*selectie: momenteel niet studerend

Tabel 7

Van plan om op een later tijdstip ( $\mathrm{nog}$ ) een opleiding te gaan volgen, naar bezigheid (\%)*

\begin{tabular}{|l|r|r|r|}
\hline Ja, ik heb mij alweer ingeschreven bij een opleiding & Werkzaam & Werkzoekend & 12 \\
\hline Ja, maar ik weet nog niet welke opleiding of wanneer & 8 & 79 & 14 \\
\hline Nee & 33 & 11 & 64 \\
\hline
\end{tabular}


zij ze relatief vaak (zeer) ontevreden over hun functie. Het percentage respondenten van het AVO dat (zeer) tevreden is met de functie is bovendien gedaald ten opzichte van vorig jaar, van $63 \%$ naar $39 \%$. Onder de respondenten van $\mathrm{MBO}$ niveau $3 / 4$ is het percentage dat (zeer) tevreden is met de huidige baan daarentegen ten opzichte van vorig jaar gestegen, van $54 \%$ naar $60 \%$.

Figuur 2

Tevredenheid met huidige functie (\%)

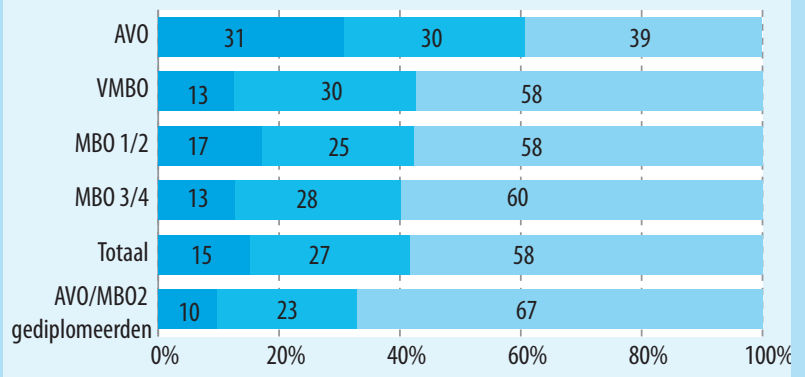

(zeer) ontevreden $\quad$ neutraal $\quad$ (zeer) tevreden

De vsv-respondenten en de respondenten met een startkwalificatie hebben relatief ongeveer even vaak het idee (heel) veel of juist (heel) weinig carrièremogelijkheden te hebben in de huidige functie. Dit geldt voor vsv-respondenten van alle opleidingsniveaus behalve het AVO. Van deze respondenten heeft de meerderheid (6I\%) het idee dat er (heel) weinig carrièreperspectieven zijn in de huidige functie.

Figuur 3

Hoeveelheid carrièremogelijkheden in huidige functie (\%)

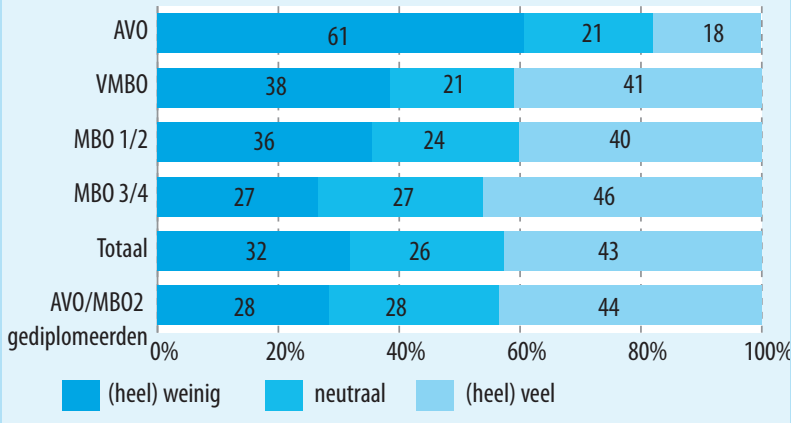

Het is niet verrassend dat veruit de meeste van de werkende vsv-respondenten (89\%) een functie hebben waarvoor geen startkwalificatie is vereist. Toch is het percentage werkende vsv-respondenten van $\mathrm{MBO}$ niveau 3/4 dat een functie heeft waarvoor het (niet behaalde) MBO niveau 3/4 diploma wordt vereist, relatief hoog (22\%). Van de werkende vsvrespondenten van $\mathrm{VMBO}$-niveau heeft de helft een functie waarvoor het (niet behaalde) VMBO-diploma wordt vereist. Van de werkende respondenten van het AVO doet veruit de meerderheid (78\%) ongeschoold werk.
Figuur 4

Vereist niveau huidige functie (anderhalf jaar na voortijdige uitval)

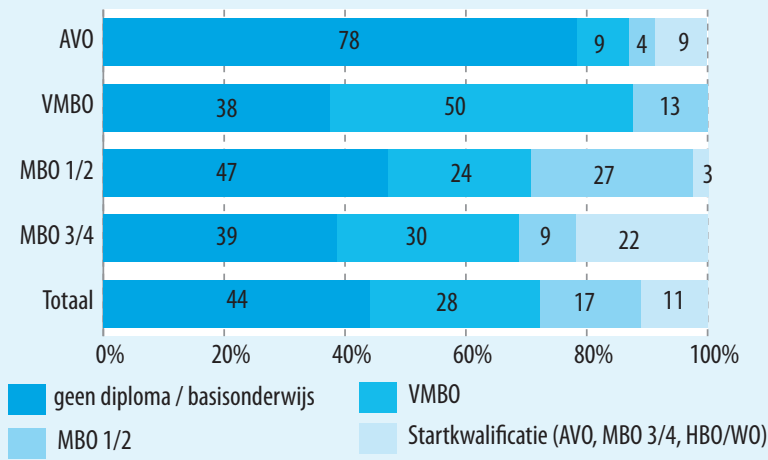

\section{Toekomstplannen en spijt achteraf}

\section{Toekomstplannen}

Tabel 6 laat van de respondenten die aangaven dat ze op enquêtemoment niet studeerden, zien wat hun toekomstplannen zijn met betrekking tot hun onderwijsloopbaan. Dit geeft een indicatie van de kans dat deze respondenten in de toekomst weer zullen terugkeren in het onderwijs of definitief niet terug naar school zullen keren.

Ongeveer een op de tien respondenten die op enquêtemoment niet studeren, staan wel ingeschreven bij een opleiding. Het gaat hier waarschijnlijk om jongeren die zich al wel hebben ingeschreven voor een opleiding, maar waarbij de opleiding nog niet is begonnen.

Het merendeel (63\%) van de respondenten die aangeven op dit moment niet te studeren, geeft aan dat ze wel van plan zijn terug te keren in het onderwijs maar dat ze niet weten welke opleiding ze willen volgen, of wanneer ze die opleiding willen gaan volgen. Ook onder de inactieven is het percentage dat dit antwoord gaf zeer hoog. Met name de niet studerende respondenten van het AVO en $\mathrm{MBO}$ niveau $3 / 4$ lijken hulp nodig te hebben bij het vinden van de juiste opleiding.

Ruim een kwart van de niet studerende respondenten is ook niet van plan om later (nog) een opleiding te gaan volgen. Met name respondenten van $\mathrm{MBO}$ niveau I/2 lijken moeilijk overtuigd te kunnen worden om (nog) een opleiding te gaan volgen. Het is zorgwekkend dat $22 \%$ van de inactieve respondenten niet van plan is om later (nog) een opleiding te gaan volgen.

Uitgesplitst naar de bezigheid van de respondenten (tabel 7), zien we dat de werkende respondenten relatief vaak aangeven dat ze niet van plan zijn om op een later tijdstip (nog) een opleiding te gaan volgen. Toch is het merendeel van hen $(59 \%)$ wel van plan om op een later tijdstip (nog) een opleiding te gaan volgen, maar weten ze niet welke opleiding of wanneer.

Bijna driekwart van de respondenten die momenteel actief werkzoekend zijn, zijn (tevens) van plan om later (nog) een opleiding te gaan volgen. 


\section{Spijt achteraf}

Aan de vsv'ers is gevraagd of, als ze kijken naar hun huidige situatie, ze er dan spijt van hebben dat ze destijds (in het schooljaar 20I0/20II) met hun opleiding zijn gestopt (tabel 8). De meerderheid ( $57 \%$ ) geeft aan achteraf bezien geen spijt te hebben van de beslissing. Respondenten van het AVO hebben relatief het minst vaak spijt van hun beslissing. De respondenten van $\mathrm{MBO}$ niveau $\mathrm{I} / 2$ en de inactieven hebben relatief het vaakst spijt van hun beslissing. Vergeleken met de respondenten van MBO niveau I/2 geven de inactieven echter relatief vaker aan dat ze destijds niet anders konden.

Uitgesplitst naar de belangrijkste reden voor de voortijdige uitval, zien we dat de respondenten die zijn gestopt vanwege schoolgerelateerde oorzaken of andere redenen relatief het minst vaak spijt hebben van hun beslissing om voortijdig te stoppen.

De respondenten die waren gestopt vanwege (geestelijke) gezondheidsklachten of persoonlijke problemen hebben relatief vaker spijt van hun beslissing. Toch geeft ongeveer de helft van hen aan dat ze destijds niet anders konden. Dit is met name opvallend omdat er tegenwoordig wel heel veel andere mogelijkheden beschikbaar zijn.

Respondenten die waren gestopt vanwege persoonlijke problemen of arbeidsmarkt gerelateerde oorzaken, geven relatief het vaakst aan dat ze spijt hebben van hun beslissing en het nu niet meer zouden doen. Dit lijkt aan te geven dat vsv'ers die dreigden uit te vallen vanwege persoonlijke problemen of vanwege arbeidsmarkt gerelateerde oorzaken, achteraf bezien relatief het best te overtuigen waren geweest om toch een startkwalificatie te behalen.

\section{Conclusies}

Dit factsheet heeft de antwoorden op een vijftal vragen beschreven. De belangrijkste bevindingen zijn:

- 'Schoolgerelateerde oorzaken' is nog steeds de meest genoemde belangrijkste reden voor voortijdige uitval. Het percentage dat deze reden als de belang- rijkste reden noemt is in drie jaar gestegen van $4 \mathrm{I} \%$ naar $5 \mathrm{I} \%$.

- Hoewel de meeste respondenten destijds met iemand hadden gesproken over hun beslissing om met de opleiding te stoppen, zijn degenen met wie ze daarover spraken niet altijd effectief geweest in het inschakelen van hulp om de uitval te voorkomen. $42 \%$ van de respondenten die met iemand over hun beslissing om te stoppen hadden gesproken hebben niet het idee dat de school of andere instanties hebben geprobeerd hun uitval te voorkomen.

- $76 \%$ van de respondenten heeft anderhalf jaar na de voortijdige uitval als belangrijkste bezigheid studeren of werken. De respondenten van het VMBO zijn het meest kwetsbaar op de arbeidsmarkt; 40\% van hen is werkloos en de baankenmerken van degenen die wel werk hebben gevonden zijn relatief slecht.

- $63 \%$ van de respondenten die aangeven op enquêtemoment (anderhalf jaar na de voortijdige uitval) niet te studeren, geeft aan dat ze wel van plan zijn terug te keren in het onderwijs maar dat ze niet weten welke opleiding ze willen volgen, of wanneer ze die opleiding willen gaan volgen.

- $22 \%$ van de inactieven is niet van plan om later (nog) een opleiding te gaan volgen.

- Een kleine meerderheid (57\%) geeft aan achteraf bezien geen spijt te hebben van de beslissing om voortijdig met de opleiding te stoppen.

Tabel 8

Spijt achteraf (\%)

\begin{tabular}{|l|r|r|r|r|r|r|}
\hline & AVO & VMBO & MBO 1/2 & MBO 3/4 & Totaal & totaal inactieven (NEET) \\
\hline Nee & 69 & 62 & 50 & 59 & 57 & 49 \\
\hline Ja, maar ik kon destijds niet anders & 28 & 30 & 34 & 30 & 31 & 38 \\
\hline Ja, dat zou ik nu niet meer doen & 3 & 9 & 16 & 12 & 12 & 13 \\
\hline Totaal & 100 & 100 & 100 & 100 & 100 & 100 \\
\hline
\end{tabular}

Tabel 9

Spijt achteraf, naar belangrijkste reden voortijdige uitval (\%)

\begin{tabular}{|l|r|r|r|r|r|r|}
\hline & Schoolgerelateerde oorzaken & (geestelijke) gezondheidsklachten & Persoonlijke problemen & Arbeidsmarkt & Anders & Totaal \\
\hline Nee & 62 & 42 & 35 & 54 & 77 & 57 \\
\hline Ja, maar ik kon destijds niet anders & 26 & 50 & 47 & 29 & 19 & 31 \\
\hline Ja, dat zou ik nu niet meer doen & 12 & 8 & 18 & 17 & 4 & 12 \\
\hline Totaal & 100 & 100 & 100 & 100 & 100 & 100 \\
\hline
\end{tabular}




\section{Bijlagen}

Tabel B1

Achtergrondkenmerken respondenten (\%)

\begin{tabular}{|c|c|c|c|c|c|c|}
\hline & AVO & VMBO & $\mathrm{MBO} 1 / 2$ & $\mathrm{MBO} 3 / 4$ & Totaal & $\begin{array}{r}\text { Totaal } \\
\text { inactieven (NEET) }\end{array}$ \\
\hline Totaal & 7 & 19 & 35 & 40 & 100 & 27 \\
\hline Gemiddelde leeftijd (jaren) & 18 & 17 & 20 & 20 & 19 & 19 \\
\hline \multicolumn{7}{|l|}{ Geslacht } \\
\hline $\operatorname{man}$ & 44 & 49 & 57 & 46 & 50 & 46 \\
\hline vrouw & 57 & 51 & 43 & 54 & 50 & 54 \\
\hline \multicolumn{7}{|l|}{ Etniciteit } \\
\hline Westerse allochtoon & 8 & 8 & 7 & 7 & 7 & 9 \\
\hline Niet-westerse allochtoon & 7 & 21 & 22 & 16 & 18 & 21 \\
\hline Autochtoon & 85 & 71 & 71 & 78 & 75 & 71 \\
\hline \multicolumn{7}{|l|}{ Gezinssamenstelling } \\
\hline Tweeouder gezin & 69 & 54 & 54 & 50 & 53 & 43 \\
\hline É́nouder gezin & 18 & 29 & 21 & 25 & 24 & 26 \\
\hline Ik woon zelfstandig & 8 & 4 & 11 & 14 & 11 & 13 \\
\hline Anders, namelijk & 6 & 14 & 15 & 11 & 12 & 18 \\
\hline
\end{tabular}

Spreektaal ouders

(bijna) altijd Nederlands

\begin{tabular}{|l|l|l|l|l|l|}
87 & 69 & 64 & 74 & 70 & 68 \\
\hline
\end{tabular}

Nederlands en een andere taal

\begin{tabular}{|l|r|r|r|r|}
\hline 6 & 15 & 10 & 12 \\
\hline
\end{tabular}

(bijna) altijd een andere taal

Niet van toepassing

35

Opleidingsniveau ouders

Vader

\begin{tabular}{|c|c|c|c|c|c|c|}
\hline Basisonderwijs & 2 & 11 & 12 & 6 & 8 & 8 \\
\hline Lager beroepsonderwijs & 15 & 29 & 37 & 28 & 30 & 30 \\
\hline Voortgezet onderwijs & 6 & 7 & 5 & 9 & 7 & 8 \\
\hline Middelbaar beroepsonderwijs & 15 & 24 & 28 & 29 & 27 & 27 \\
\hline Hoger onderwijs & 62 & 29 & 18 & 28 & 27 & 26 \\
\hline \multicolumn{7}{|l|}{ Moeder } \\
\hline Basisonderwijs & 2 & 10 & 13 & 5 & 8 & 9 \\
\hline Lager beroepsonderwijs & 10 & 31 & 38 & 32 & 32 & 34 \\
\hline Voortgezet onderwijs & 13 & 9 & 9 & 7 & 8 & 10 \\
\hline Middelbaar beroepsonderwijs & 19 & 27 & 29 & 34 & 30 & 28 \\
\hline Hoger onderwijs & 55 & 24 & 12 & 22 & 21 & 20 \\
\hline \multicolumn{7}{|l|}{ Kinderen } \\
\hline Ja & 1 & 3 & 7 & 4 & 5 & 9 \\
\hline Nee & 99 & 97 & 93 & 96 & 95 & 91 \\
\hline
\end{tabular}


Tabel B2

Belangrijkste reden voor voortijdige uitval (\%)

\begin{tabular}{|c|c|c|c|c|c|c|c|}
\hline & & AV0 & VMBO & MBO 1/2 & $\mathrm{MBO} 3 / 4$ & Totaal & Totaal inactieven (NEET) \\
\hline \multirow[t]{12}{*}{ Schoolgerelateerde oorzaken } & de opleiding was te moeilijk en/of gezakt voor het eindexamen & 27 & 4 & 10 & 6 & 8 & 6 \\
\hline & problemen op de leerwerkplek/stage (bijv. ontslag) & 0 & 2 & 11 & 4 & 6 & 6 \\
\hline & problemen met de leraren/schoolleiding & 3 & 7 & 4 & 4 & 4 & 4 \\
\hline & problemen met andere leerlingen & 2 & 2 & 1 & 1 & 1 & 1 \\
\hline & (wilde van opleiding of school wisselen) & 5 & 8 & 4 & 8 & 6 & 4 \\
\hline & ik voelde me niet veilig op school & 0 & 2 & 1 & 0 & 1 & 1 \\
\hline & de opleiding was inhoudelijk (toch) niet wat ik wilde & 1 & 8 & 9 & 16 & 11 & 9 \\
\hline & ik vond het niveau van de opleiding te laag & 1 & 4 & 3 & 3 & 3 & 1 \\
\hline & de opleiding was slecht georganiseerd & 6 & 4 & 6 & 11 & 8 & 6 \\
\hline & (onvoldoende begeleiding) & 1 & 1 & 0 & 0 & 0 & 1 \\
\hline & (indicatie speciaal onderwijs) & 0 & 2 & 0 & 0 & 0 & 0 \\
\hline & (overige schoolgerelateerde problemen) & 3 & 2 & 1 & 1 & 1 & 1 \\
\hline Subtotaal & & 49 & 45 & 50 & 54 & 51 & 39 \\
\hline \multirow{3}{*}{$\begin{array}{l}\text { (geestelijke) } \\
\text { Gezondheidsklachten }\end{array}$} & (fysieke gezondheidsproblemen (ziekte/handicap)) & 12 & 6 & 7 & 7 & 7 & 11 \\
\hline & verslavingsproblemen & 0 & 1 & 2 & 1 & 1 & 1 \\
\hline & psychische problemen & 15 & 11 & 6 & 8 & 8 & 12 \\
\hline Subtotaal & & 27 & 18 & 14 & 16 & 16 & 24 \\
\hline \multirow[t]{5}{*}{ Persoonlijke problemen } & relatie/gezinsproblemen (bijv. scheiding van ouders) & 5 & 7 & 7 & 4 & 6 & 7 \\
\hline & zwangerschap & 0 & 1 & 2 & 2 & 2 & 4 \\
\hline & school icm zorg voor kinderen en/of familie was te zwaar & 0 & 1 & 1 & 0 & 1 & 1 \\
\hline & in aanraking gekomen met politie/justitie & 1 & 1 & 1 & 0 & 1 & 1 \\
\hline & (overige persoonlijke problemen) & 2 & 2 & 1 & 3 & 2 & 3 \\
\hline Subtotaal & & 9 & 12 & 11 & 10 & 11 & 15 \\
\hline \multirow[t]{3}{*}{ Arbeidsmarkt } & ik wilde liever gaan werken & 1 & 6 & 11 & 7 & 8 & 9 \\
\hline & ik had een inkomen nodig en ben daarom gaan werken & 0 & 1 & 6 & 4 & 4 & 4 \\
\hline & (ik kon geen leerwerkplek/stage vinden) & 0 & 1 & 2 & 1 & 1 & 0 \\
\hline Subtotaal & & 1 & 8 & 19 & 12 & 13 & 14 \\
\hline \multirow[t]{3}{*}{ Anders } & ik ging verhuizen & 8 & 6 & 1 & 1 & 2 & 2 \\
\hline & anders & 5 & 10 & 4 & 7 & 6 & 5 \\
\hline & (door school gedwongen te stoppen of verblijfsvergunning) & 1 & 1 & 1 & 0 & 1 & 1 \\
\hline Subtotaal & & 14 & 17 & 6 & 8 & 9 & 8 \\
\hline Totaal & & 100 & 100 & 100 & 100 & 100 & 100 \\
\hline
\end{tabular}




\section{Colofon}

(C) Researchcentrum voor Onderwijs en Arbeidsmarkt (ROA). Niets uit deze uitgave mag op enige manier worden verveelvoudigd zonder voorafgaande schriftelijke toestemming van de directeur van het ROA.

Researchcentrum voor Onderwijs en Arbeidsmarkt Maastricht University

School of Business and Economics

secretary-roa-sbe@maastrichtuniversity.nl

www.roa.nl

\section{Vormgeving}

ROA secretariaat, Maastricht 
Researchcentrum voor Onderwijs en Arbeidsmarkt

Postbus 616

6200 MD Maastricht

$\mathrm{T}+31433883647$

F +31 433884914

secretary-roa-sbe@maastrichtuniversity.nl

www.roa.nl

Maastricht University

School of Business and Economics 